thus the average value this year is $£ 67$ per ton. Australia and South Africa are now the chief customers for British chemical plant. Great Britain also imports chemical plant, and since there is increasing activity in the chemical industry, the amount of this has increased more than three-fold since 1935, though there are now signs of abatement. The average value per ton this year is $£ 143$. Most of the plant, which is generally of a highly specialized nature, has come from Germany. These figures give no indication of the activities of the British plant manufacturers in the home trade, but the same number of the Industrial Chemist seeks to remedy this by several pages of pictures of actual plant and new equipment which has been delivered this year, featured under the heading of "Progress".

\section{Forest Products Research}

THE report of the Forest Products Research Board for the year 1935 has been issued by the Department of Scientific and Industrial Research (London : H.M. Stationery Office, 1936). The report includes the report of the director of the Researeh Laboratory at Princes Risborough for the same year. The Board itself met only once during the year, when various pieces of research work under investigation were considered, as also the possibility of establishing a substation of the Laboratory in Seotland. The Board noted with appreciation that there was direct evidence of interest by industries concerned in the manufacture of both wooden and fibre-board boxes, as well as by users of such boxes, of the facilities now available in the new box-testing laboratory. The investigations into the physical properties of timber which have a direct influence on its behaviour during seasoning and when in use have been advanced; and the results, it is considered, promise ultimately to be of material importance to architects and others engaged in industries dependent upon timber. As a result of visits to the Laboratory by many representatives of firms engaged in the manufacture of timber and timber goods, and instructors in building science or woodworking at various technical schools, some of whom have spent periods of varying lengths at the Laboratory, a new departure has been instituted. To minimize the interference with the routine work which such visits involved, a short educational course of one week's duration was given in September of which full advantage was taken.

\section{An Alchemical Manuscript}

IN a reprint from Osiris $(2,220 ; 1936)$, W. J. Wilson, of the Library of Congress, Washington, deals with a treatise copied by Arnaldus de Bruxella at Naples between 1473 and 1490 , and purchased by Lehigh University, Pennsylvania, in 1881 for the price of ten dollars. It is a compendium of chemical and alchemical recipes of a type fairly well known through other manuseipts of similar date in Paris and elsewhere. Mr. Wilson gives an account of the contents of the manuscript with extracts, which are translated, and an index of names and technical terms. He shows how its contents are related to other treatises, and deals in separate sections with the origin and development of alchemical tradition, the operations of alchemy, allegorical and mystical aspects of alchemy and its relations to magic and medicine. This commentary, which is the fruit of a careful study of texts and literature on the history of alchemy, is provided with an excellent bibliography and is of very considerable value in presenting an accurate and concise statement of the position of modern research into the origins of alchemy and early chemistry. The scholarly treatment is on a much higher level than many accounts in that it takes into consideration the Chinese and Indian sources, without which no modern study can be said to have any particular significance.

\section{Decline in Malaria in Soviet Russia}

As the result of the energetic measures adopted by the Soviet authorities, the incidence of malaria in the U.S.S.R. has greatly declined. According to Prof. Sergiyev, head of the Malaria Department of the Commissariat of Health and director of the Central Tropical Institute, during the first six months of 1936 there was a drop of about 35 per cent in the number of malaria cases and of 40 per cent in the number of deaths from malaria as compared with the corresponding period of 1935 . With the object of destroying the malaria-carrying mosquitoes, two and a half million infested areas were sprayed with oil, partly by aeroplanes. Mosquito netting was introduced into the badly infested areas. 100 motorcars and 260 microseopes were supplied to the malaria stations. During the summer, 500 doctors and senior students took part in the anti-malarial campaign, which was carried on by 1,800 permanent malaria organizations.

\section{Tropical Pathology and Microbiology}

OwING to the increasing number of papers in the field of special pathology and microbiology hitherto published in the Chinese Medical Journal, which is primarily intended for clinical contributions, this material will now be published in a Supplement to the Chinese Medical Journal, of which the first number was issued last February. It forms a volume of the same size and format as the Journal, and contains 500 pages of text with 70 plates, and is published by the Chinese Medical Journal, Peiping, China, price $10 s$. The contents are divided into the three subjects : (1) pathology, (2) bacteriology and (3) parasitology. In addition, there is a valuable paper by R. J. C. Hoeppi on "Methods of Illustrating Scientific Papers", in which the apparatus for, and technique of, drawing, and the main processes now used for reproduction of illustrations, are described.

\section{Museum Exhibits de luxe}

At last the limit of the nature-group method of exhibiting museum specimens seems to have been reached, for Science Service announces that Prof. 